\title{
Analyzing Face Threatening Act in WhatsApp Group
}

\author{
Wulan Nuraeni' ${ }^{1}$, Noer Aripin Wibowo ${ }^{2}$ \\ ${ }^{1}$ IKIP SILIWANGI \\ ${ }^{2}$ IKIP SILIWANGI \\ ${ }^{1}$ wulansaja664@gmail.com, ${ }^{2}$ noer.aripin@yahoo.com
}

\begin{abstract}
As human being people will always interact each other every day, in every situation there are probability where someone can be threatened. Every interaction contains utterance where threatened can be happened in order to threaten both of speakers and hearer which is called Face Threatening Act or known as FTA. This research purpose was to found out the kind function of FTA in politeness that might be applied on the group chat between student with another student and student with the lecturer. The research took the places in WhatsApp group of college student of IKIP Siliwangi Bandung, Cimahi, Indonesia which consist 38 respondents. This research used a descriptive qualitative and the data taken from the results of questionnaire as an instrument. Based on the data from finding section that founded most of college students used a positive politeness when communicated with other students even though there was small percentage showed some of student used negative politeness as well.
\end{abstract}

Keyword: Pragmatic, politeness, utterance, face threatening act.

\section{INTRODUCTION}

Human is social creature that have the need to communicate with others, language is the first aspect of communication. Language used by people around the world in order to do any communication. In any communication there are speaker and hearer communicate each other where make a result of meaning interpretation. In order to know further about meaning there is a study called pragmatic. According to (Yule, 1996) pragmatic is "concerned with study of meaning as communicated by a speaker (or writer) and interpreted by a listener (or reader)". It is mean pragmatic focuses into study of meaning in communication which needed to be understood by a listener or reader in order to get what the speaker or writer try to deliver. Furthermore, author also stated that pragmatic is "study of contextual meaning", this is mean the speakers need to organize what they want to deliver by also looking into what, where, when and under what circumstances. Each condition if not organized carefully by the speaker or writer can refer into different result of what listener or reader achieve. Similar with (Horn \& Ward, 2007) that state pragmatic is "the study of those context-dependent aspects of meaning which are systematically abstracted away from in the construction of content or logical form". He stated that pragmatic is the study of context-dependent aspect which is needed to construct systematically and contain indirectly meaning of content itself.

However, in order to deliver a meaning the speakers need to do an utterance. According to (Hurford, Heasley, \& Smith, 2007) utterance is "any stretch of talk, by one person, before and after which there is silence on the part of that person." The author state that utterance is condition where any talk that happened after or before the silences between the people, in other word that utterance is when person started to talk again. Similar with the (Goded Rambaud, 2011) that state utterance is can be "created by speaking or writing a piece of language", it is 
means an utterance is when someone tried to speak or write language even only a single word. Based on the definition above researchers can conclude that utterance is the situation when someone tried to speak or write a word or sentences after the silences.

When doing an utterance, the use of politeness is also important, because people cannot utter any utterance without looking for their addressee; politeness is a fundamental part of culture which shapes human behaviour within society. According to (Yule, 1996) politeness is "a system of interpersonal relations designed to facilitate interaction by minimizing the potential for conflict and confrontation inherent in all human interchange." He stated that politeness is a system that used by speaker when interact with other to minimize all of potential conflict that may happen in the communication. According to (Kedveš, 2013) he stated that politeness can be classified into four different categories which according to the inherent functions of communication acts. The classification are: 1) The convivial function, this function used when illocutionary and social communication aim coincide in example speakers try to greeting, congratulating, offering, inviting, etc.; 2) The collaborative function, this function used when illocutionary and social communication are independent as speakers try to declare, assert, report, announce, etc. 3) The competitive function, this function used when illocutionary goal are compete with social goal in example speakers try to order, ask, demand, beg, etc. and 4)

The conflicting function, this function used when illocutionary and social communication contain conflict goals as speaker try to threaten, accuse, etc. which generally express negative feelings and reaction.

In other hand, (Brown \& Levinson, 1987) stated that politeness applied by speakers contain different purpose and strategies. That strategy is bald on record, positive politeness, negative politeness and off record.

a) Bald on record is politeness strategy spoken to interlocutors directly about purpose of them, commonly used sentences in the form of a command line imperative sentence, for example "'put on your shoes!' this strategy have many category between which explain in this analysis that is emergency; task oriented, request, and alerting. Emergency in that urgent condition this strategy conversation often using by speaker and interlocutors, as example 'watch out!'. Task oriented is conversation strategy when what is mean by speaker to follow interlocutors, example "'turn the light off!" Request is strategy for extend interlocutors urge immediately way. Example "'lend me your duty!". Alerting is strategy category bald and record used by speaker to give warning or sentence alert to interlocutors, example is 'Beware! Don't drink while driving',

b) Positive politeness is strategy politeness used by speaker and interlocutors, and they who are close and familiar to us. The sentence used is usually a friendly language. This strategy has too much strategy there are attend to the hearer, avoid disagreement, assume disagreement, and hedge opinion. Attend to the hearer used when speaker want to be more friendly with interlocutors. The sentence which is spoken make listener or interlocutors feel comfortable or respected. Avoid disagreement be used when they want avoid debate because has dissent with interlocutors. Assume agreement is strategy be used for achievement and draw conclusion that interlocutors agreed with speaker. Hedge opinion is where speaker objective adjust from conversation to give suggestion interlocutors to avoid interlocutors from feel uncomfortable and offended.

Before start to do any conversation, usually speaker understands about interlocutors, where speaker find if interlocutor a higher or the social status is high. So they stacking and then applied language do conversation with who are speaker he spoke. If social status be different they usually will communicate an employees and superiors. 
If interlocutors they are the peoples have to social status which have same degrees or a close relationship, so they interaction will feel informal as close friends.

Politeness is something should be owned by everyone in doing interaction and communication. Thus the relationship between speaker and interlocutors entwined will good.

However, in any kind of communication there will contain a face threatening act. According to (Yule, 2006) face-threatening act is when speaker say any word or sentences that threat to another persons' self-image. Similar to (Brown \& Levinson, 1987) that stated all of speech act is FTA. In other word, it is mean face-threatening act can be happened on all of communication and speech act.

(Brown \& Levinson, 1987) state that there two kinds of FTA which are negative FTA and positive FTA. He stated that negative face-threatening acts is the acts that directly for the hearer with indicate the speaker does not intend to avoid impeding hearer freedom of action, for example: orders, requests, suggestion, offers, promises, compliments, etc. In contrast he state positive face-threatening acts is the acts that threaten positive-face want, this is indicated by that the speaker does not care about hearer feelings, wants, etc. For example: criticism, disagreement, challenges, irreverence, expression of violent, bringing of bad news, etc.

Furthermore, (Brown \& Levinson, 1987), distinct FTA according to who get threaten, in this case both of hearer and speaker possible to get a FTA. He stated that are two kinds of another threatening act may happened to the speaker, that is 1) offend speaker negative face and 2) directly damage speaker positive face. Offend speaker negative face such as expressing thanks, acceptance of hearer thanks, acceptance of hearer apology, acceptance of offers, response to hearer faux pas, unwilling promises and offers. In other hand, directly damage speaker positive face such as apologies, acceptance of compliments; break down of physical control body, selfhumiliation, confessions, and emotion leakage.

Based on the description above, researcher's interest did a research about politeness in WhatsApp group IKIP Siliwangi Bandung and their communication activity not only with friends and around area but with some lecturer which have different social status with lecturer. The researchers do a research under title "Analyzing Face Threatening Act in WhatsApp Group"

\section{METHOD}

This research was designed by using qualitative method to mean phenomena about what experienced by the subject of researchers as attitude, motivation, action and others holistic and descriptive the way in the word and linguistic, in a specifics contexts with some method (Moleong, 2007).

The technique used was questionnaire, questionnaire which makes in link and divided in groups to obtain the answers. Because this research in group so the main instrument of this research were students in WhatsApp group IKIP Siliwangi Bandung. The data were taken from the utterance answered of questionnaires in the WhatsApp group IKIP Siliwangi.

After got the data, and then the next way was analyzed the data and researchers used qualitative data analysis.

Qualitative data analysis can be described as the process of making sense from research participants views and opinions of situations, corresponding patterns, themes, categories and regular similarities (Cohen, Manion, \& Morrison, 2007). (Marshall \& Rossman, 1999) describe data analysis as the process data bringing of order structure and the meaning mass of collect data. 
The researchers used document analysis because the data here were in the form written or visual material. In order to analyzed the data, the researchers find there are several step such as: the researchers starts to make questionnaire same with using theory, after that researchers make link addressed for share questionnaire in group whatsap IKIP and after respondent was collect researchers start to collecting answer data respondent for researchers make a conclusion strategy politeness which the using respondent. The last step, the researchers tried to describe the context FTA by using Brown and Levinson theory.

\section{RESULTS AND DISCUSSION}

\section{Results}

Based on the question given to respondents, the researchers described the answer based on the item. These answers would describe respondents' understanding about the type of politeness sentence.

Question one asked the respondents' response about the sentence that a lecturer said when he give an assignment in the end of meeting. There were four (11.1\%) respondents choose 'Saya akan memberikan tugas Minggu depan, silahkan membuat chapter report' (I will give a task for next week, please make a chapter report). There were twenty (55.5\%) answered 'Buat chapter report dan dikumpulkan pada pertemuan selanjutnya' (Class, you have to make a chapter report and collect it in the next meeting), and twelve (33.3\%) respondents stated 'silahkan membuat chapter report dan tolong dikumpulkan Minggu depan' (Class, please make a chapter report and collect it in the next meeting). Based on data above, the correct answer is 'Buat chapter report dan dikumpulkan pada pertemuan selanjutnya' (Class, you have to make a chapter report and collect it in the next meeting), It can be concluded that students used negative politeness. It can be showed by twenty (55.5\%) respondents.

Question two asked the respondents' response about the sentence that used when student's asked about the task to the lecturer. There were two $(5.5 \%)$ respondents written statement 'bisa saya tahu tugas pertemuan sekarang, pak/bu?' (May I know the task for this meeting, Mr/Mrs?). There were twenty nine (80.5\%) replied 'mohon maaf, apakah tugas pertemuan sekarang?' (I am sorry, any task for today meeting?). There were five (13.8\%) respondents selected 'apakah tugasnya, pak/bu?' (What is the task, Mr/Mrs?). Based on data above, the correct answer is mohon maaf, apakah tugas pertemuan sekarang?' (I am sorry, any task for today meeting?), It can be concluded that students used negative politeness. It can be showed by twenty nine $(80.5 \%)$ respondents.

Question three asked the respondents' response about the sentence that used when student's asked the task to her/his friend's. There were twenty five (69.4\%) respondents decided 'tugasnya apaan?' (What is the task?). There were seven (19.4\%) established 'apakah ada tugas?' (Is there any task for today?). There were four (11.1\%) respondents secured 'Bisakah saya menanyakan tugas pertemuan sekarang?' (May I ask the task for today meeting?). Based on data above, the correct answer is 'tugasnya apaan?' (What is the task?). It can be concluded that students used positive politeness. It can be showed by twenty five $(69.4 \%)$ respondents.

Question four asked the respondents' response about the sentence that used when the lecturer learning material is outside the topic. There were seven (19.4\%) respondents choose 'sepertinya materi yang disampaikan bapak/ibu diluar konteks' (I think material which delivered by you Mr/Mrs is outside of the material context). There were twenty seven (75\%) answered 'mohon maaf, bapak/ibu, materi ini memberikan pengetahuan tambahan bagi kami namun bagaimana kami bisa membuat kesimpulan dari materi ini?' (Sorry Mr/Mrs, this material gives us the new knowledge, but how can we make a summary from this material?). There were two (5.5\%) respondents stated 'materi bapak/ibu sangat bertolak belakang dengan 
materi sebelumnya, bagaimana kami dapat membuat kesimpulan berdasarkan materi pertemuan sekarang?' (The material that Mr/Mrs delivered so contrary with previous material, how can we make summary based on today meeting?). Based on data above, the correct answer is 'mohon maaf, bapak/ibu, materi ini memberikan pengetahuan tambahan bagi kami namun bagaimana kami bisa membuat kesimpulan dari materi ini?' (Sorry Mr/Mrs, this material gives us the new knowledge, but how can we make a summary from this material?). It can be concluded that students used negative politeness. It can be showed by twenty seven (75\%) respondents.

Question five asked the respondents' about the sentence that the lecturer as the supervisor used in examination when give a warning. There were seven (19.4\%) respondents vote jangan berisik!' (Do not be noisy!). There were one (2.7\%) answered 'boleh kerja sendiri?' (May I do it alone?). There were twenty eight (77.7\%) respondents prefer 'diharapkan untuk bekerja sendiri!' (Please do it by yourself!). Based on data above, the correct answer is 'jangan berisik!' (Do not be noisy!). This cannot be concluded that lecturer used bald and record, because they did not understand the use of the command sentence. It can be showed by seven $(19.4 \%)$ respondents.

Question six asked the respondents' about the sentence that the students' ask of the task answer. There were twenty five (69.4\%) respondents make a choice 'jawaban no lima apa?' (What is the answer for number five?). There were six (16.6\%) elected 'boleh minta jawaban no lima?' (May I ask for an answer for number five?). There were five (13.8\%) respondents opt 'nomor lima udahkan?' (You had answered number five, aren't you?) Based on data above, the correct answer is 'jawaban no lima apa?' (What is the answer for number five?). It can be concluded that students used positive politeness. It can be showed by twenty five $(69.4 \%)$ respondents.

Question seven asked the respondents' about the sentence that asks friend doing campus task. There were twenty eight (77.7\%) respondents choose 'bantuin yah ngerjain tugas' (Help me for doing the tasks okay?). There were five (13.8\%) answered 'kan kemarin aku sudah bantuin, sekarang giliran' (Yesterday I helped you, now it is your turn to help me). There were three $(8.3 \%)$ respondents stated 'bantuin ih' (Help me!). Based on data above, the correct answer is 'bantuin yah ngerjain tugas' (Help doing the tasks okay?). It can be concluded that students used positive politeness. It can be showed by twenty eight $(77.7 \%)$ respondents.

Question eight asked the respondents' about the sentence that asked friend to the position of you as presenter in courses certain. There were thirteen $(36.1 \%)$ respondents choose saya gak siap, gantikan saya' (I am not ready, handle my position). There were twelve (33.3\%) answered 'maaf, boleh gantikan saya?' (Sorry, can you handle my position?). There were eleven (30.5\%) respondents stated 'saya kemarin ga sempat mempersiapkan materi, bisa gantiin?' (Yesterday, I did not prepare the material yet, could you handle my position?). Based on data above, the correct answer is 'saya kemarin ga sempat mempersiapkan materi, bisa gantiin?' (Yesterday, I did not prepare the material yet, could you handle my position?) This cannot be concluded that students used bald and record, because they did not understand the uses of the command sentence that contains to follow what speaker mean. It can be showed by eleven $(30.5 \%)$ respondents.

Question nine asked the respondents about the sentence that talking about discussion and need to take a decision. There were eleven (30.5\%) respondents choose 'jadi kita sepakat untuk melakukan ini' (So we agreed to do this). There were twenty one (58.3\%) answered 'jadi, langkah apa yang akan kita ambil? (So, what the step we will take?). There were four (11.1\%) respondents stated 'pokoknya kesimpulanya adalah...' (Anyway, the summary is...). Based on data above, the correct answer is 'jadi kita sepakat untuk melakukan ini' (So we agreed to do this). This cannot be concluded that student's positive politeness, because they did not 
understand the use of the sentence that shows the speaker and the listener agreed from a decision of the discussion. It can be showed by eleven (30.5\%) respondents.

Question ten asked the respondents' about the sentence that asking a settlement the topic on the lecturer. There were twenty five (69.4\%) respondents choose 'saya kurang faham dengan materi ini, bisakah bapak/ibu menjelaskan kembali materi ini' (I did not understand about this material, could Mr/Mrs repeat this material again?). There were seven (19.4\%) answered 'menurut saya materi ini sangat menarik, namun pada bahasan ini saya kurang memahami pointnya. Bisakah diulang kembali penjelasanya?' (I think this material interesting, but I did not understand the main point. Could repeat that?). There were four (11.1\%) respondents stated 'bisakah bapak/ibu mengulang penjelasan pada bagian ini?' (Would you mind repeating that material?). Based on data above, the correct answer is saya kurang faham dengan materi ini, bisakah bapak/ibu menjelaskan kembali materi ini (I did not understand about this material, could Mr/Mrs repeat this material again). It can be concluded that students used bald on record. It can be showed by twenty five $(69.4 \%)$ respondents.

\section{Discussion}

Based on the finding section that researchers can conclude the results of the research. Researchers describe the results as the follows:

Question one showed that thirty-eight $(100 \%)$ respondents filled the questionnaires. Based on the data, researchers can conclude that lecturer often used instruction utterance. three (7.89\%) respondents strongly disagree. Five (13.1\%) respondents disagree. Seven (18.4\%) respondents stated neutral. Fifteen (39.4\%) respondents agree, and eight $(21.5 \%)$ respondents strongly agree.

Question two showed that thirty-eight $(100 \%)$ respondents filled the questionnaires. Based on the data, researchers can conclude that most of those students when asked the tasks to lecturer used apologise utterance. No respondents choose strongly disagree. Two $(5.2 \%)$ respondents disagree. Six $(5.7 \%)$ respondents stated neutral. Sixteen $(42.1 \%)$ respondents agree. Eight $(21.5 \%)$ respondents strongly agree.

Question three showed that thirty-eight (100\%) respondents filled the questionnaires. Based on the data, researchers can conclude that most of those students when asked the tasks to his/her friend used fine utterance. No respondents choose strongly disagree. Four $(10.5 \%)$ respondents disagree. Seven $(18.4 \%)$ respondents stated neutral. Twenty three $(60.5 \%)$ respondents stated agree. and four $(10.5 \%)$ respondents strongly agree.

Question four showed that thirty-eight (100\%) respondents filled the questionnaires. Based on the data, researchers can conclude that most of those students when did not understand material used direct utterance. One (2.6\%) respondent strongly disagrees. Eight $(21 \%)$ respondents disagree. fourteen (36.8\%) respondents neutral. thirteen $(34.2 \%)$ respondents agree. and two $(5.2 \%)$ respondents strongly agree.

Question five showed that thirty-eight $(100 \%)$ respondents filled the questionnaires. Based on the data, researchers can conclude that lecturer used instruction utterance in examination. No respondent choose strongly disagree. Four (10.5\%) respondents disagree. Four $(10.5 \%)$ respondents stated neutral. Eighteen $(47.3 \%)$ respondents agree. And twelve $(31.5 \%)$ respondents strongly agree.

Question six showed that thirty-eight (100\%) respondents filled the questionnaires. Based on the data, researchers can conclude that most of those students used directly utterance for the wishes. One $(2.6 \%)$ respondent strongly disagrees. Three $(7.8 \%)$ respondents disagree. Eleven $(28.9 \%)$ respondents stated neutral. Twenty one $(55.2 \%)$ respondents agree. And two $(5.2 \%)$ respondents strongly agree. 
Question seven showed that thirty-eight (100\%) respondents filled the questionnaires. Based on the data, researchers can conclude that most of those students used instruction utterance to the wishes. No respondent choose strongly disagree. Nine (23.6\%) respondents disagree. Fifteen $(39.4 \%)$ respondents stated neutral. Eleven $(28.9 \%)$ respondents agree. Three (7.8\%) respondents strongly agree.

Question eight showed that thirty-eight (100\%) respondents filled the questionnaires. Based on the data, researchers can conclude that most of those students used constrain utterance. Five $(13.1 \%)$ respondent strongly disagree. Sixteen $(42.1 \%)$ respondents disagree. Six $(15.7 \%)$ respondents stated neutral. Eight $(21 \%)$ respondents agree. And three (7.8\%) respondents strongly agree.

Question nine showed that thirty-eight (100\%) respondents filled the questionnaires. Based on the data, researchers can conclude that most of those students used direct for constrain utterance. Five $(13.1 \%)$ respondent strongly disagree. Thirteen $(34.2 \%)$ respondents disagree. Nine (23.6\%) respondents stated neutral. Ten (26.3\%) respondents agree. And one (2.6\%) respondent strongly agrees.

Question ten showed that thirty-eight $(100 \%)$ respondents filled the questionnaires. Based on the data, researchers can conclude most of those students' used suggestion utterance. No respondent choose strongly disagree. Six $(15.7 \%)$ respondents disagree. Twelve $(31.5 \%)$ respondents stated neutral. Seventeen (44.7\%) respondents agree. And three (7.8\%) respondents strongly agree.

\section{CONCLUSION}

Based on data of the research, researchers concluded that results from 10 questions shows most of respondents use a negative politeness and directly with smooth utterance when students talking with their lecturer, such as asking a task. From data of questionnaire researchers can conclude that Bald on record the most function that used inside learning and teaching process, in example when lecturer give the task for his/her students, also used when students ask about something to their friend use imperative statement. Based on the research data also founded that most of students used forgiveness statement to their lecturer in order to avoid utterance that might not accepted by their lecturer. Also from the data there founded positive politeness that used by speakers and hearers that was really close. From this research, researchers found that most of students used fine sentences. In other hand, students often use an advice or suggestion for asking another explanation to their lecturer when they still did not understand.

\section{ACKNOWLEDGMENTS}

Alhamdulillah all gratitude to Allah S.W.T who gave His blessing to researchers, so researchers can finish this article with good health condition. Researchers would like to say the biggest thank you for researchers' article supervisors who always gave researchers support when conducting this research. Also, researchers would like to say thank you to IKIP Siliwangi Bandung which gave us opportunity to publish this article. Also for blind reviewer who were reviews this article as well as to the editorial team so this article can be published perfectly.

\section{REFERENCES}

Brown, P., \& Levinson, S. C. (1987). Politeness: some universals in language usage. Cambridge University Press.

Cohen, L., Manion, L., \& Morrison, K. (2007). Research Methods in Education, Sixth Edition. 
Routledge, Taylor \& Francis group (Vol. 38).

https://doi.org/10.1080/19415257.2011.643130

Goded Rambaud, M. (2011). Basic semantics. UNED.

Horn, L., \& Ward, G. (2007). The handbook of pragmatics. Blackwell Publishing Ltd.

Hurford, J. R., Heasley, B., \& Smith, M. B. (2007). Semantics : a coursebook (Second). Cambridge University Press.

Kedveš, A. (2013). Jezikoslovlje. Jezikoslovlje (Vol. 14). Fak.

Marshall, C., \& Rossman, G. B. (1999). Designing Qualitative Research. Journal of Marketing Research (Vol. 27). https://doi.org/10.2307/3172595

Moleong, L. J. (2007). Metodologi penelitian kualitatif. PT Remaja Rosdakarya.

Yule, G. (1996). Pragmatics. Oxford University Press.

Yule, G. (2006). The study of language (Third). Cambridge University Press. 